\title{
Pengaruh Vaksin BCG dalam Meningkatkan Proses Regresi Seluler pada Lesi Prakanker Serviks Uteri Derajat Rendah
}

\author{
Yudi Mulyana Hidayat, ${ }^{1}$ Putut Giri Saputro, ${ }^{2}$ Dodi Suardi, ${ }^{1}$ Gatot NA Winarno, ${ }^{1}$ \\ Siti Salima, ${ }^{1}$ Ali Budi Harsono ${ }^{1}$ \\ ${ }^{1}$ Departemen Obstetri dan Ginekologi Fakultas Kedokteran Universitas Padjadjaran/ \\ RSUP Dr. Hasan Sadikin Bandung \\ ${ }^{2}$ Rumah Sakit Islam Jakarta Pondok Kopi \\ Korepondensi:yudi.mulyana@unpad.ac.id
}

\begin{abstract}
Abstrak
Tujuan: Penelitian ini adalah untuk menganalisis peranan pemberian vaksin bacille calmette-guerin (BCG) terhadap proses regresi seluler pada lesi prakanker serviks uteri derajat rendah

Metode: Penelitian ini merupakan penelitian eksperimental dengan rancangan pretest (IVA dan Histopatologi) - posttest (IVA dan Test HPV DNA) with control design di Poliklinik Rumah Sakit Dr. Hasan Sadikin Bandung pada bulan Desember 2017-Maret 2018.

Hasil: Untuk pemeriksaan IVA bulan ke-0 pada kelompok BCG kategori positif sebanyak 9 (100.0\%) sedangkan untuk pemeriksaan IVA bulan ke-3 pada kelompok BCG kategori positif sebanyak $3(33.3 \%)$ dan negatif menjadi sebanyak 6 (66.7\%), pemeriksaan tes HPV DNA bulan ke 12 pada kelompok BCG kategori positif HPV DNA High Risk tidak ditemukan ( $0 \%$ ). Hasil uji statistik pada kelompok perlakuan diperoleh nilai $\mathrm{p}<0.05$. Untuk pemeriksaan IVA bulan ke-0 pada kelompok plasebo kategori positif sebanyak $9(100.0 \%)$ sedangkan untuk pemeriksaan IVA bulan ke-3 pada kelompok plasebo kategori positif sebanyak 8 (88.9\%) dan negatif menjadi sebanyak 1 (11.1\%). pemeriksaan tes HPV DNA bulan ke 12 kelompok BCG kategori positif HPV DNA High Risk sebanyak 1 orang ( 11,1\%). Hasil uji statistik pada kelompok kontrol diperoleh informasi nilai $\mathrm{p}>0.05$.

Kesimpulan: Terdapat peranan pemberian vaksin BCG terhadap regresi seluler lesi prakanker serviks derajat rendah.
\end{abstract}

Kata Kunci: Vaksin BCG, pemeriksaan IVA, tes HPV DNA, lesi prakanker serviks derajat rendah.

\section{The effect of Bacille Calmette-Guerin vaccine on regression of cervical intraepithelial neoplasia-1}

\begin{abstract}
Objective: The aim of this study was to analyze the role of Baccile Calmete Guerin (BCG) vaccines delivery in low grade precancerous cervical lesions.

Methods: The design of the study was a pretest and posttest experimental with control, done at Hasan Sadikin Hospital Bandung Outpatient Clinic during December 2017-March 2018.

Result: Patients with positive VIA test in the intervention group in month-0 were 9 patients (100.0\%), in month-3 were 3 patients (33.33\%) and the other 6 patients (66.7\%) changed into negative. Patients with positive VIA test in the control group in month-0 were 9 patients (100.0\%), in month 3 were 8 patients $(88.9 \%)$ and the other 1 patients (11.1\%) changed into negative. The result of statistical analysis in the intervention group was $p<0.05$. The result of statistical analysis in the control group was $p>0.05$.

Conclusion: : there is a role of BCG vaccine in low grade precancerous cervical lesions.
\end{abstract}

Key words: BCG vaccine, VIA test, Low grade cervical precancerous lesions. 


\section{Pendahuluan}

Kanker serviks adalah kanker primer dari serviks (endoserviks dan ektoserviks). Lesi prakanker serviks merupakan awal dari perubahan menuju kanker serviks. ${ }^{1,2}$ Infeksi human papillomavirus (HPV) risiko tinggi merupakan faktor etiologi kanker serviks. Penelitian yang dilakukan oleh International Agency for Research on Cancer (IARC) terhadap 1.000 sampel dari 22 negara mendapatkan adanya infeksi HPV pada sejumlah 99,7\% kanker serviks. ${ }^{3}$ Menurut American Social Health Association, sekitar 6,2 juta orang di Amerika Serikat terinfeksi HPV setiap tahunnya. ${ }^{4}$ Pada tahun 2012, Information Centre on HPV and Cervical Cancer menunjukkan data prevalensi HPV di populasi wanita Indonesia adalah sekitar $17,3 \%{ }^{5}$

Infeksi HPV high risk strain merupakan faktor risiko yang potensial untuk terjadinya kanker serviks. Virus ini akan menyebabkan perubahan pada sel epitel serviks dan mengakibatkan terjadinya cervical intraepithelial neoplasia (CIN). Persistensi HPV yang mengakibatkan kanker serviks berhubungan dengan respon imun yang diperantarai oleh sel T helper 1 (Th1). ${ }^{6}$

Infeksi HPV risiko tinggi merupakan penyebab terjadinya kanker serviks, sehingga tindakan skrining mengalami pergeseran yang semula ditujukan untuk pencegahan sekunder bergeser untuk tujuan pencegahan primer. Mencegah terjadinya infeksi HPV risiko tinggi merupakan pencegahan primer dan dianggap lebih penting, karena pencegahan sekunder mempunyai beberapa kelemahan. Berbagai macam cara mendeteksi HPV, antara lain dengan vira pap, vira type, HPV profile, hybrid capture (HC), polymerase chain reaction (PCR). Deteksi dini kanker serviks yang ideal adalah pemeriksaan papanicolaou/sitologi pap smear, baik sitologi konvensional maupun berbasis cairan, yang dikombinasikan dengan pemeriksaan DNA
HPV. Temuan pada HC dan pap smear di beberapa institusi menjadi dasar penelitian protokol skrining dan tindak lanjut hasil pemeriksaan. The Hybrid Capture yang positif harus diikuti dengan pengawasan yang ketat, kelainan sitologi harus diikuti dengan terapi, sedangkan hasil negatif keduanya menjadi dasar pemberian vaksinasi HPV. ${ }^{2}$

Inspeksi visual dengan asam asetat (IVA) adalah pemeriksaan serviks secara langsung tanpa menggunakan alat pembesaran setelah pengusapan serviks dengan asam asetat $3-5 \%$. Pemeriksaan ini bertujuan untuk mendeteksi secara dini adanya lesi prakanker serviks atau kanker serviks melalui perubahan warna epitel serviks menjadi putih yang disebut acetowhite. ${ }^{7,8}$ Beberapa hasil dari penelitian mendapatkan bahwa pemeriksaan IVA dan pemeriksaan pap smear mempunyai kemampuan yang hampir sama dalam mendeteksi secara dini lesi prakanker serviks dan sesuai apabila digunakan di pusat pelayanan sederhana. ${ }^{8}$ Sensitivitas dan spesifitas skrining dengan menggunakan pemeriksaan IVA sebesar $71,8 \%$ dan $79,4 \%{ }^{7}$ Berbagai penelitian menyebutkan bahwa skrining dengan pemeriksaan IVA lebih mudah, praktis, sederhana, nyaman, dan murah dibandingkan dengan pap smear. ${ }^{8}$

Human Pavilloma Virus (HPV) mebutuhkan sel inang ( sel serviks uteri) untuk replikasi atau virus memperbanyak diri dan setelah sel inang (host) dipergunakan untuk kepentingan replikasi virus, sel akan ditinggalkan dengan meninggalkan sequele kemampuan sel inang (serviks uteri) tumbuh otonom akibat tumor supressor gen $\mathrm{Rb}$ (retinoblstoma) dan p53 ditekan fungsinya oleh protein E 6 dan E7 HPV. Sel otonom tersebut berkembang menjadi sel yang displastic menjadi lesi prakanker serviks ( CIN I, CIN 2 dan CIN 3). Pada lesi prakaknker serviks derajat rendah (CIN I) sebagian besar (70\%) akan mengalami regresi sel menjadi normal kembali dan sebagian kecil (30\%) dapat berkembang menjadi derajat tinggi 
( CIN 2, 3). Kemampuan sel dengan lesi prakaknker serviks derajat rendah (CIN 1) kembali menjadi normal sangat tergantung pada sistem imun tubuh wanita yang terinfeksi virus HPV ( Immune Serveillance). 1,2,5

Penggunaan imunomodulator seperti vaksin bacille calmette-guerin (BCG) diketahui dapat meningkatkan keberhasilan terapi kanker, misalnya pada kanker paru dan kandung kemih.9,10 Bacille calmette-guerin menyebabkan aktivasi makrofag dengan terjadinya peningkatan fagositosis, aktivitas antimikroba, metabolisme makrofag, dan kemampuan makrofag untuk membunuh sel tumor. ${ }^{9}$ Penelitian dengan menggunakan vaksin BCG sebagai modulator pada kanker serviks stadium II dan III telah dilakukan oleh Iskandar TM di Semarang, akan tetapi peranan BCG pada proses regresi sel dan pencegahan perkembangan ke arah kanker serviks belum pernah dilakukan.Vaksin BCG adalah modulator non-spesifik yang dapat meningkatkan respons imun seluler penderita karsinoma melalui peningkatan peran monosit dan sel natural killer (sel NK). Pemberian vaksin pada penderita kanker serviks diharapkan berguna sebagai pencegahan maupun terapi yang mengacu pada immune surveillance theory. Diharapkan peningkatan respons imun seluler akan meningkatkan kejadian complete response yang dinilai berdasarkan respons radiasi histologis dan juga akan menurunkan angka kekambuhan penderita kanker serviks yang sudah mendapat terapi kemoradiasi. ${ }^{11}$

Mekanisme vaksin BCG sebagai anti-tumor belum diketahui secara jelas, tetapi banyak dihubungkan dengan respon imunologi seperti aktivasi sel $\mathrm{T}$, makrofag, sel NK dan sel B. Tujuan penelitian ini adalah untuk menilai regresi infeksi HPV melalui pemeriksaan IVA pada penderita lesi prakanker serviks derajat rendah yang telah mendapat vaksin BCG dan telah dilakukan pengamatan selama tiga bulan.

\section{Metode}

Subjek penelitian adalah pasien yang berobat di Poliklinik sub bagian Onkologi Ginekologi RSUP Dr. Hasan Sadikin Bandung pada periode desember 2017 sampai dengan Maret 2018 dengan hasil pemeriksaan inspeksi visual asam asetat $3-5 \%$ (IVA) positif yang kemudian dilakukan kolposkopi dan dilanjutkan biopsi terarah dengan hasil biopsi cervical intraepithelial neoplasia-1 (CIN 1).

Penelitian ini telah mendapatkan persetujuan dari komite etik Rumah Sakit Umum Dr. Hasan Sadikin dengan no ref LB.04.02/A05/EC/328/XI/2017. Pasien yang diikut sertakan adalah pasien yang memenuhi kriteria inklusi dan bersedia mengikuti penelitian setelah diberi penjelasan dan menandatangani formulir persetujuan (informed consent).

Penelitian ini merupakan penelitian eksperimental dengan rancangan pretest posttest with control design. ${ }^{12}$ Pada penelitian ini, sejumlah subyek pasien dengan hasil pemeriksaan inspeksi visual asam asetat 3-5\% (IVA) positif yang kemudian dilakukan kolposkopi dan dilanjutkan biopsi terarah dengan hasil biopsi cervical intraepithelial neoplasia-1 (populasi studi) dibagi dalam dua kelompok, yakni kelompok yang mendapat suntikan BCG dosis 0,5 cc intralesi diberikan 1 kali (kelompok perlakuan) dan kelompok yang mendapat suntikan plasebo (kelompok kontrol) dengan cara randomisasi. Luaran yang dinilai adalah hasil pemeriksaan IVA pada bulan ketiga dan pemeriksaan tes HPV DNA high Risk pada bulan ke 12 setelah perlakuan.

Berdasarkan data bahwa penggunaan imunomodulator seperti vaksin bacille calmette-guerin (BCG) menyebabkan aktivasi makrofag dengan terjadinya peningkatan fagositosis, aktivitas antimikroba, metabolisme makrofag dan kemampuan makrofag untuk membunuh sel tumor. Peneliti menggunakan batas waktu 
3 bulan untuk melihat efek pemberian vaksin $\mathrm{BCG}$ terhadap pasien dengan hasil pemeriksaan IVA positif dan pemeriksaan tes HPV DNA High Risk bulan ke 12 untuk melihat adanya regresi sel dengan melihat ekspresi tes HPV DNA High Risk. Studi penelitian eksperimen merupakan salah satu analisis untuk mengetahui pengaruh suatu perlakuan terhadap parameter yang diukur.

Penarikan sampel dilakukan secara consecutive sampling, yaitu berdasarkan urutan kedatangan pasien yang memenuhi kriteria inklusi sampai terpenuhi besar sampel minimal. Penentuan besar sampel disesuaikan dengan tujuan penelitian dan tipe data pada penelitian, maka dengan menggunakan rumus penentuan besar sampel untuk penelitian analitis. ${ }^{12}$ Pada penelitian ini desain yang digunakan adalah analitis kategorik tidak berpasangan. Penentuan besar sampel ditentukan berdasarkan taraf kepercayaan 95\% dan kuasa uji (power pemeriksaan) 90\%. Dengan menggunakan rumus penentuan besar sampel untuk penelitian analitis kategorik tidak berpasangan diperlukan jumlah sampel untuk kelompok kasus sebanyak 9 orang dan kelompok kontrol sebanyak 9 orang. Sehingga total jumlah sampel sebesar 18 orang. Dari data yang terkumpul selanjutnya dianalisis secara deskriptif dan analitik. Untuk deskriptif dengan menyajikan ukuran statistik jumlah dan persentase untuk data kategori, sedangkan untuk data numerik dengan menyajikan rata-rata, simpang baku, median dan rentang. Untuk perhitungan analitik dengan menggunakan uji statistik. Uji statistik yang digunakan pada penelitian ini adalah uji t tidak berpasangan digunakan untuk membandingkan perbedaan dua ratarata data berdistribusi normal, jika data tidak berdistribusi normal digunakan uji MannWhitney, uji normalitas data menggunakan uji Shapiro-Wilk, uji Chi-kuadrat untuk menganalisis perbedaan dua proporsi hasil Pemeriksaan IVA, jika ada nilai ekspektasi sel $<5$ digunakan uji eksak Fisher. Uji chi- square untuk data kategorik apabila syarat Chi-Square terpenuhi, bila terpenuhi maka digunakan uji Exact Fisher untuk table 2 x 2 dan Kolmogorov Smirnov untuk tabel selain 2 x 2, uji Mc Nemar pemeriksaan untuk membandingkan kemaknaan karakteristik kelompok penelitian data kategorik sebelum dan sesudah perlakuan.13 Kemaknaan hasil uji ditentukan berdasarkan nilai $\mathrm{p}<0,05$. Data yang diperoleh dicatat dalam formulir khusus kemudian diolah melalui program SPSS versi 24.0 for Windows. 14

\section{Hasil}

Populasi target pada penelitian ini adalah pasien yang melakukan pemeriksaan di Poliklinik Rumah Sakit Dr. Hasan Sadikin Bandung pada bulan Desember 2017 sampai dengan Maret 2018 yang memenuhi kriteria inklusi. Pasien dengan hasil pemeriksaan inspeksi visual asam asetat $3-5 \%$ (IVA) positif yang kemudian dilakukan kolposkopi dan dilanjutkan biopsi terarah dengan hasil biopsi cervical intraepithelial neoplasia 1 (CIN 1). Setiap subjek penelitian dicatat identitas, nomor rekam medis, usia, paritas, indeks masa tubuh, hasil patologi anatomi, foto serviks pra-perlakuan dan pascaperlakuan.

Pasien dengan hasil biopsi CIN 1 secara acak dilakukan pemberian suntikan BCG atau pemberian suntikan plasebo yang kemudian akan dilakukan observasi dan pemeriksaan IVA setelah 3 bulan dan pemeriksaan tes HPV DNA High Risk di Laboratorium Prodia Jl. Wastukencana Bandung setelah 12 bulan. Pasien akan dijelaskan mengenai prosedur penelitian. Pada penelitian ini subjek penelitian yang memenuhi kriteria inklusi adalah 18 pasien, terdiri dari 9 sampel untuk kelompok pasien yang diberikan suntikan vaksin BCG (kelompok perlakuan) dan 9 sampel untuk kelompok pasien yang diberikan suntikan plasebo (kelompok kontrol).Karakteristik subjek penelitian peranan pemberian vaksin 
Tabel 1 Karakteristik Subjek Penelitian

\begin{tabular}{cccc}
\hline \multirow{2}{*}{ Karakteristik } & \multicolumn{2}{c}{ Perlakuan } & \\
\cline { 2 - 3 } & $\begin{array}{c}\text { BCG } \\
(\mathbf{n}=9)\end{array}$ & $\begin{array}{c}\text { Placebo } \\
\text { (n=9) }\end{array}$ & \\
\hline Usia (tahun) & & & \\
$\quad$ Rerata (SD) & $39.2(6.9)$ & $48.0(13.8)$ & 0.10 \\
Rentang & $29-50$ & $28-68$ & \\
Paritas & & & \\
Median & 3 & 2 & 0.96 \\
Rentang & $0-4$ & $1-8$ & \\
IMT (kg/m $\left.{ }^{2}\right)$ & & & \\
Rerata (SD) & $23.0(2.8)$ & $23.4(3.4)$ & 0.75 \\
Rentang & $19.5-27.3$ & $18.3-28.4$ &
\end{tabular}

Keterangan: *) untuk usia dan IMT dengan uji t tidak berpasangan, sedangkan paritas dengan uji Mann-Whitney

Tabel 2 Perbandingan antara Pemeriksaan IVA pada Lesi Prakanker Serviks Derajat Rendah Bulan Ke-0 dan Bulan Ke-3 pada Kelompok Perlakuan dengan BCG dan Plasebo.

\begin{tabular}{lcccc}
\hline \multirow{2}{*}{ Perlakuan } & \multicolumn{3}{c}{ Pemeriksaan IVA } & \multirow{2}{*}{ Nilai p*) } \\
\cline { 2 - 4 } & $\begin{array}{c}\text { Bulan ke-0 } \\
\text { Positif }\end{array}$ & $\begin{array}{c}\text { Bulan ke-3 } \\
\text { Positif }\end{array}$ & Negatif & \\
\hline BCG $(\mathrm{n}=9)$ & 9 & $3(33.3 \%)$ & $6(66.7 \%)$ & $0.00 *$ \\
Plasebo (n=9) & 9 & $8(88.9 \%)$ & $1(11.1 \%)$ & 0.30 \\
\hline
\end{tabular}

Keterangan: Untuk Data kategorik nilai p dihitung berdasarkan uji McNemar. Nilai kemaknaan berdasarkan nilai $\mathrm{p}<0.05$. Tanda* menunjukkan nilai $\mathrm{p}<0.05$ artinya signifkan atau bermakna secara statistik

BCG terhadap regresi seluler pada lesi prakanker serviks derajat rendah berdasarkan usia, paritas, indeks masa tubuh, dan perlakuan dengan BCG dan Plasebo dapat dilihat pada tabel 1 .

Tabel 1 Menjelaskan bahwa berdasarkan karakteristik usia diketahui nilai rerata dan standar deviasi untuk kelompok kontrol lebih besar yaitu sebesar 48.0 (13.8) dan kelompok perlakuan sebesar 39.2 (6.9). Karakteristik paritas diketahui nilai median untuk kelompok perlakuan adalah 3 dengan rentang paritas adalah 0-4 dan nilai median untuk kelompok kontrol adalah 2 dengan rentang paritas adalah 1-8. Karakteristik indeks masa tubuh (IMT) diketahui nilai rerata dan standar deviasi untuk kelompok kontrol lebih besar yaitu sebesar 23.4 (3.4) dan kelompok perlakuan sebesar 23.0 (2.8). Kategori usia, paritas, dan IMT pada kedua kelompok penelitian tidak menunjukkan ada perbedaan yang bermakna dengan nilai $\mathrm{p}>0.05$, dengan homogenitas karakteristik ini maka layak dapat diperbandingkan dan dilakukan uji statistik lebih lanjut.

Tabel 2 menyajikan perbandingan hasil pemeriksaan IVA pasca pemberian BCG (perlakuan) dan pemberian plasebo (kontrol). Dari tabel menjelaskan pada kelompok perlakuan, 3 pasien $(33.3 \%)$ menunjukkan hasil pemeriksaan IVA positif, dan 6 pasien (66.7\%) menunjukkan hasil pemeriksaan IVA 

Tabel 3 Perbandingan Hasil Pemeriksaan Tes HPV DNA High Risk pada Lesi Prakanker
Serviks Derajat Rendah Bulan Ke 12 antara Kelompok BCG dan Placebo

\begin{tabular}{|c|c|c|c|}
\hline \multirow[t]{2}{*}{ Perlakuan } & \multicolumn{2}{|c|}{$\begin{array}{c}\text { Pemeriksaan Tes HPV DNA High Risk } \\
\text { Bulan ke-12 }\end{array}$} & \multirow[t]{2}{*}{ Nilai $\mathbf{p}^{*}$} \\
\hline & Positif & Negatif & \\
\hline $\mathrm{BCG}(\mathrm{n}=9)$ & $0(\%)$ & $9(100 \%)$ & $0.00^{*}$ \\
\hline Plasebo $(n=9)$ & $8(88.9 \%)$ & 1(11.1\%) (HPV16) & 0.30 \\
\hline
\end{tabular}

negatif. Pada kelompok kontrol, 8 pasien (88.9\%) menunjukkan hasil pemeriksaan IVA positif, dan 1 pasien (11.1\%) menunjukkan hasil pemeriksaan IVA negatif.

Tabel 3 menyajikan perbandingan hasil pemeriksaan tes HPV DNA High Risk 12 bulan pasca pemberian BCG (perlakuan) dan pemberian plasebo (kontrol). Tampak pada kelompok perlakuan (BCG) 12 bulan pasca pemberian tidak didapatkan ekspresi HPV DNA High Risk, sedangkan pada kelompok kontrol ( Placebo) 1 kasus ekspresi HPV DNA High Risk (+) type 16.

\section{Pembahasan}

Peranan vaksin antibodi HPV baik yang bivalent atau quadrivalent hanya bersifat preventive Vaccine (mencegah virus HPV merusak sel jika telah menginfeksi sel serviks) sedangkan vaksin yang bersifat terapeutik belum ada sampai saat ini dan pada kasus lesi prakanker serviks derajat rendah (CIN I) dapat terjadi regresi spontan atau kembali normal secara alamiah dengan kemampuan sistem imune tubuh yang ada, pada penelitian ini diharapkan pemberian vaksin BCG dapat mempercepat proses regresi sel prakanker derajat rendah (CIN 1) menjadi normal kembali lebih cepat atau dapat membantu sistem imune tubuh dibandingkan pada kasus yang tidak diberikan baksin BCG. ${ }^{2}$

Pilihan penanganan pasien dengan lesi pra kanker derajat rendah saat ini adalah observasi dan pemantauan pap smear tiap
4 sampai 6 bulan, dilakukan kolposkopi jika terdeteksi kelainan segera dilakukan kolposkopi dan pemeriksaan HPV. ${ }^{2}$ Penelitian oleh Lee, dkk. memperlihatkan bahwa administrasi BCG intravesika telah terbukti efektif melawan kanker kandung kemih superfisial. Pengikatan komponen IgG pada imunoblot mewakili protein yang dimiliki menjadi lebih peka akibat imunoterapi BCG intravesika. ${ }^{15}$

Penelitian oleh Hoffmann, dkk. menyimpulkan pemberian BCG intravesika untuk kanker kandung kemih yang berisiko tinggi dan non-muscle invasif serta karsinoma in situ adalah salah satu imunoterapi paling baik hingga saat ini. Percobaan pada hewan telah menunjukkan bahwa generasi sel efektor, yang disebut BCG-activated active killer, tergantung pada helper $\mathrm{T}$ tipe 1 (Th1) -tipe sitokin. Pada manusia, profil Th1-biased sitokin urin yang tinggi setelah beberapa minggu pemberian BCG intravesika berhubungan dengan respon klinis yang lebih baik. $^{10}$

Penelitian lainnya oleh Pines pada 48 pasien dengan kanker paru-paru skuamosa sel lanjut diterapi dengan radikal radioterapi. Setelah itu, 25 pasien menerima vaksin BCG secara teratur dan 23 pasien tidak diberikan. Perbedaan pada kedua kelompok dalam pengamatan pada kelangsungan hidup selama tahun pertama dan tidak adanya metastasis perifer secara signifikan mendukung pasien yang diobati dengan BCG lebih baik. ${ }^{9}$

Vaksin BCG menyebabkan aktivasi 
makrofag dengan terjadinya peningkatan sistem fagositosis, aktivitas anti-mikrobal, metabolisme makrofag dan kemampuan makrofag untuk membunuh sel tumor. Rapp menunjukkan bahwa pada marmut yang dicangkok dengan hepatoma dan mendapat injeksi BCG ternyata mampu menghilangkan benjolan lokal dan mengeradikasi sel tumor dalam pembuluh getah bening. Hal ini disebabkan adanya reaksi silang antara BCG dengan tumor. ${ }^{16}$ Bukti terbaru menunjukkan bahwa dapat terjadi reaksi antigen BCG dengan sel melanoma. Gynecology Oncology Group (GOG) melakukan penelitian lain terhadap adenokarsinoma ovarium lanjut pada kasus sub-optimal dengan sisa tumor besar pada stadium III dan IV, diacak antara kelompok cisplatin, doksorubicin dan siklofosfamid (CAP) versus CAP plus $\mathrm{BCG}$, namun hasilnya tidak menunjukkan perbedaan bermakna. ${ }^{17}$ Pada percobaan binatang, diketahui bahwa BCG mempunyai kemampuan mengatasi endotoksin dengan mengaktivasi makrofag sehingga terjadi peningkatan fagositosis. Pada manusia, BCG digunakan melalui tiga jalur yaitu injeksi intralesi, pemakaian sistemik secara intradermal, serta mencampur dengan sel dan digunakan sebagai vaksin. ${ }^{18}$

Penelitian Albert dkk pada keganasan ovarium, didapatkan kombinasi kemoterapi dengan BCG ternyata dapat meningkatkan remisi dan survival dibandingkan dengan yang hanya mendapat kemoterapi. ${ }^{19}$ Penggunaan imunoterapi BCG secara lokal banyak digunakan pada terapi kanker vesica urinaria, yang penggunaannya disuntikkan ke dalam vesica. ${ }^{10,15}$ Penelitian Lamm juga mendapatkan pemberian BCG $5 \mathrm{mg}$ secara perkutan setelah reseksi tumor kandung kemih yang dikombinasi dengan radioterapi intravesika, hasilnya menunjukkan interval bebas penyakit dan menurunkan rekurensi. Dikatakan juga BCG dapat digunakan sebagai vaksin terapi kanker, dengan tujuan penggunaannya mendorong reaksi imun terhadap antigen vaksin. Pemakaian BCG dikatakan dapat meningkatkan sistem retikuloendotelial, meningkatkan kapasitas makrofag untuk melakukan fagositosis serta meningkatkan ketahanan terhadap infeksi dan mencegah implantasi tumor. ${ }^{20}$

Dalam meningkatkan imunitas seluler, vaksin BCG berperan dalam mengaktifkan makrofag dan sel dendrit untuk meningkatkan berbagai sitokin, antara lain Il-1, Il-2, Il-5, Il6, Il-10, Il-12, TNF $\alpha$, IFN $\gamma$, macrophage colony stimulating factor (M-CSF) disamping mengaktivasi sel T, makrofag, sel NK, sel B serta MHC kelas II. ${ }^{11,15,20}$

Pada lesi prakanker, pemberian BCG akan menimbulkan folikel limfosit yang akan menimbulkan lymphoplasmacellular dan reaksi makrofag. Vaksin BCG akan meng-encode protein L1 dan E7 yang akan merangsang E7 spesifik antibodi dan respons imun, disamping itu juga akan mempengaruhi sel dendritik sehingga mempunyai kemampuan untuk mempresentasikan antigen dan memperpanjang ekspresi antigen. ${ }^{21}$ Gutterman dkk melaporkan efek imunoterapi adjuvan dengan BCG $6 \times 10^{8}$ viabel unit secara skarifikasi pada hari ke-9, 13, dan 17 dikombinasi dengan kemoterapi (fluorourasil, adriamycin, cyclophosphamide) pada kanker payudara stadium lanjut, hasilnya menunjukkan efek BCG dalam meningkatkan survival secara bermakna. ${ }^{22}$

Pasien dengan lesi serviks derajat rendah dapat mengalami regresi spontan. Pada sebagian besar pasien, infeksi akan hilang dalam 9 hingga 15 bulan. CIN 1 terbanyak merupakan infeksi HPV jinak dan akan mengalami regresi spontan pada lebih dari $60 \%$ kasus. $^{2}$

Hasil penelitian ini diharapkan dapat bermanfaat untuk penggunaan vaksin BCG sebagai salah satu pilihan terapi pada lesi pra kanker derajat rendah dalam membantu proses regresi sel prakanker serviks kembali menjadi normal lebih cepat dibandingkan dengan regresi dengan proses alamiah. 
Perlu penelitian lebih lanjut untuk peranan vaksin $B C G$ sebagai vaksin terapeutik pada lesi prakaknker derajat rendah maupun lesi derajat tinggi.

\section{Conflict Of Interest}

Penulis menyatakan tidak ada konflik kepentingan pada penelitian ini

\section{Saran dan Ucapan Terimakasih}

Penulis ingin mengucapkan terimakasih kepada Depatmen Obstetri dan Ginekologi, RSUP Dr. Hasan Sadikin, dan dr. Aisyah Shofiatun Nisa, MMR untuk kontribusinya dalam membantu proses publikasi penelitian ini.

\section{Daftar Pustaka}

1. Meijer CJ,Berkhof J, Castle PE, Hesselink AT, Franco EL, Ronco G, et al. Guidelines for human papillomavirus DNA test requirements for primary cervical cancer screening in women 30 years and older. INT J CANCER. 2009;124(3):516-20.

2. Andrijono. Kanker serviks. 1 ed. Jakarta: Balai Penerbit FKUI; 2007.

3. Clifford G, Gallus S, Herrero R, Munoz N, Snijders P, Vaccarella S, et al. Worldwide distribution of human papillomavirus types in cytologically normal women in the International Agency for Research on Cancer HPV prevalence surveys: a pooled analysis. The Lancet. 2005;366(9490):991-8.

4. Bao YP, Li N, Smith JS, QIAO YL. Human papillomavirus type distribution in women from Asia: a meta $\square$ analysis. Int J Gynecol Cancer. 2008;18(1):71-9.

5. WHO/ICO. Information centre on HPV and cervical cancer. Human papilloma virus and related diseases report. INDONESIA. Summary report update 2012 Lc 2012. [cited: 2017 July 29] Available from http://www.who.int/ hpvcentre.

6. Woodman $\mathrm{CB}$, Collins $\mathrm{S}$, Winter $\mathrm{H}$,
Bailey A, Ellis J, Prior P, et al. Natural history of cervical human papillomavirus infection in young women: a longitudinal cohort study. The Lancet. 2001;357(9271):1831-6.

7. Sauvaget C, Fayette JM, Muwonge R, Wesley R, Sankaranarayanan R. Accuracy of visual inspection with acetic acid for cervical cancer screening. Int J Gynecol Cancer. 2011;113(1):14-24.

8. Wiyono S, Iskandar TM, Suprijono S. Inspeksi visual asam asetat (IVA) untuk deteksi dini lesi prakanker serviks. Media Medika Indonesiana. 2008;43(3):116-21.

9. Pines A. A 5-year controlled study of BCG and radiotherapy for inoperable lung cancer. The Lancet. 1976;307(7956):380-1.

10. Hoffmann P, Roumeguere T, Schulman C, Van Velthoven R. Use of statins and outcome of BCG treatment for bladder cancer. $N$ Engl $\mathrm{J}$ Med. 2006;355(25):2705-7.

11. Iskandar TM, Mexitalia M, Sarjadi S, Dharmana E, Pramono N. Respons Histopatologik Karsinoma Serviks Uteri Setelah Pemberian Kemoradiasi. MEDIA MEDIKA INDONESIANA. 2011;45(3):174-80.

12. Gordis L. Epidemiology. Saunders. Elsevier Philadelphia, PA: 2009

13. Conte JM. A review and critique of emotional intelligence measures. J O B. 2005;26(4):433-40.

14. Field A. Discovering statistics using IBM SPSS statistics. Sage; 2013.

15. Um S, Lee S, Yang D. 10 Hypersensitivity Pneumonitis Following Intravesical Bacille Calmette-Guerin Immunotherapy for Superficial Bladder Cancer. J Investig Allergol Clin Immunol. 2009;19(3):230.

16. Zbar B, Rapp HJ. Immunotherapy of guinea pig cancer with BCG. Cancer. 1974;34(S8):1532-40.

17. Luca S, Mihaescu T. History of BCG vaccine. Maedica (Buchar). 
2013;8(1):53-8.

18. Gatfield J, Pieters J. Essential role for cholesterol in entry of mycobacteria into macrophages. Science. 2000;288(5471):1647-51.

19. Frizzera G, Gajl-Peczalska KJ, Burgess A, Einhorn L, Buzdar AU, Richman SP, et al. CANCER-VOL. 43. CANCER RESEARCH. 1979;39(4).

20. Lamm DL. Prophylaxis for recurrent transitional cell carcinoma. Urology. 1991;37(5):21-3.

21. Ling $\mathrm{M}, \mathrm{Wu}$ TC. Therapeutic Human Papillomavirus vaccines. Dalam: Rohan TE, Shah KV, penyunting. Cervical cancer : from etiology to prevention. London: Kluwer Academic Publisher; 2004. hlm. 345-75.

22. Hortobagyi GN, Gutterman JU, Blumenschein GR, Tashima CK, Burgess MA, Einhorn L, et al. Combination chemoimmunotherapy of metastatic breast cancer with 5fluorouracil, adriamycin, cyclophosphamide, and BCG. Cancer. 1979;43(4):1225-33. 